\title{
Molecular composition and paleobotanical origin of Eocene resin from northeast India
}

\author{
Arka Rudra ${ }^{1, *}$, Suryendu Dutta $^{1}$ and Srinivasan V Raju ${ }^{2}$ \\ ${ }^{1}$ Department of Earth Sciences, Indian Institute of Technology Bombay, Powai, Mumbai 400 076, India. \\ ${ }^{2} R \& D$ Department, Oil India Limited, Duliajan, Assam 786 602, India. \\ *Corresponding author.e-mail: arudra@iitb.ac.in
}

The molecular composition of fossil resins from early to middle Eocene coal from northeast India, has been analyzed for the first time to infer their paleobotanical source. The soluble component of fossil resin was analyzed using gas chromatography-mass spectrometry (GC-MS). The resin extracts are composed of cadalene-based $\mathrm{C}_{15}$ sesquiterpenoids and diagenetically altered triterpenoids. The macromolecular composition was investigated using pyrolysis gas chromatography-mass spectrometry (Py-GC-MS) and Fourier transform infrared (FTIR) spectroscopy. The major pyrolysis products are $\mathrm{C}_{15}$ bicyclic sesquiterpenoids, alkylated naphthalenes, benzenes and a series of $\mathrm{C}_{17}-\mathrm{C}_{34} n$-alkene- $n$-alkane pairs. Spectroscopic analysis revealed the dominance of aliphatic components. The presence of cadalene-based sequiterpenoids confirms the resin to be Class II or dammar resin, derived from angiosperms of Dipterocarpaceae family. These sesquiterpenoids are often detected in many SE Asian fluvio-deltaic oils. Dipterocarpaceae are characteristic of warm tropical climate suggesting the prevalence of such climate during early Eocene in northeast India.

\section{Introduction}

Resins are sticky exudates released by plants as a result of physical injury that harden on aerial exposure. They are highly robust and resistant to degradation. They are also ecologically beneficial to plants as they repel insects, protect from herbivores and micro-organisms and prevent degradation of plant tissues by sealing and protecting wounds (van Aarssen and de Leeuw 1992; Bray and Anderson 2009). Resinites or ambers are fossilized products of higher plant resins composed of macromolecules of polymerized plant terpanes and/or phenolic compounds (Langenheim 1995; Murray et al. 1998). They are highly distinct and have been recorded with specific geographical and botanical origin in the geosphere (Anderson et al. 1992). Broadly, fossil resins are derived from angiosperms and gymnosperms (Dutta et al. 2009). The angiosperms emerged during mid-early Cretaceous whereas the evolution of conifers predates to Carboniferous (van Bergen et al. 1995). Fossil resins are well prevalent in Indian lignites of early Eocene age and their detailed geochemistry has been carried out on samples from western India (Mallick et al. 2009; Dutta et al. 2011a, b). Dutta et al. (2011a) have reported Cretaceous resins from Meghalaya, northeast India and Myanmar which are composed of abietane and labdane diterpenoids derived from mainly Pinaceae conifers. The source of the Cenozoic resins in India can be attributed mainly to angiosperm plants of Dipterocarpaceae family (Dutta et al. 2009, 2011b). These are also known as dammar resins and have been classified as Class II resins (Anderson et al. 1992; Dutta et al. 2009). These have been reported from SE Asia,

Keywords. Eocene; northeast India; resin chemistry; Dipterocarpaceae. 
central and SE North America (Anderson and Muntean 2000). These resins are characterized by the presence of cadalene-type bicyclic sesquiterpenoids and related biomarkers. They are the source of many late Cenozoic fluvio-deltaic oils from across SE Asia including some parts of eastern India and China (Huang et al. 2003; Dutta et al. 2011a).

The present study documents the chemical characterization of early to middle Eocene resins from Meghalaya, the first to be recorded, from northeastern India to assess their paleobotanical source, using gas chromatography mass spectrometry (GC-MS), pyrolysis gas chromatography mass spectrometry (Py-GC-MS) and Fourier transform infrared (FTIR) spectroscopy.

\section{Samples and methods}

\subsection{Samples}

The resin samples were collected from Langrin coal field, located in the Khasi Hills of Meghalaya in the northeastern part of India to assess their paleobotanical source. Fossil resin rich coal occurs in the Jaintia Group of Paleocene-Eocene age. The map of Langrin coal mine and the localized stratigraphy are represented in figures 1 and 2, respectively. The coal seams are associated with Lakadong sandstone (also known as Tura Formation in Garo and West Khasi hills) and were deposited in swampy and boggy environment under rheotropic to ombrotropic conditions with periodic influence of brackish water (Mukherjee et al. 1992; Singh and Singh 2000). An early to middle Eocene age was assigned to it (Behera 2007). The resins which are embedded as lumps within the coal were carefully handpicked and dried at $50^{\circ} \mathrm{C}$ for $6 \mathrm{~h}$ prior to analysis. The soluble part was extracted using dichloromethane (DCM).

\subsection{Gas chromatography-mass spectrometry}

The resin extracts were analysed by gas chromatography-mass spectrometry (GC-MS) using an Agilent 5975 mass spectrometer attached to a 7890 gas chromatograph. The GC was fitted with a DB1 fused silica capillary column $(30 \mathrm{~m} \times 0.25 \mathrm{~mm}$ i.d., $0.25 \mu \mathrm{m}$ film thickness). Helium was used as carrier gas at a flow rate of $1 \mathrm{ml} / \mathrm{min}$. The

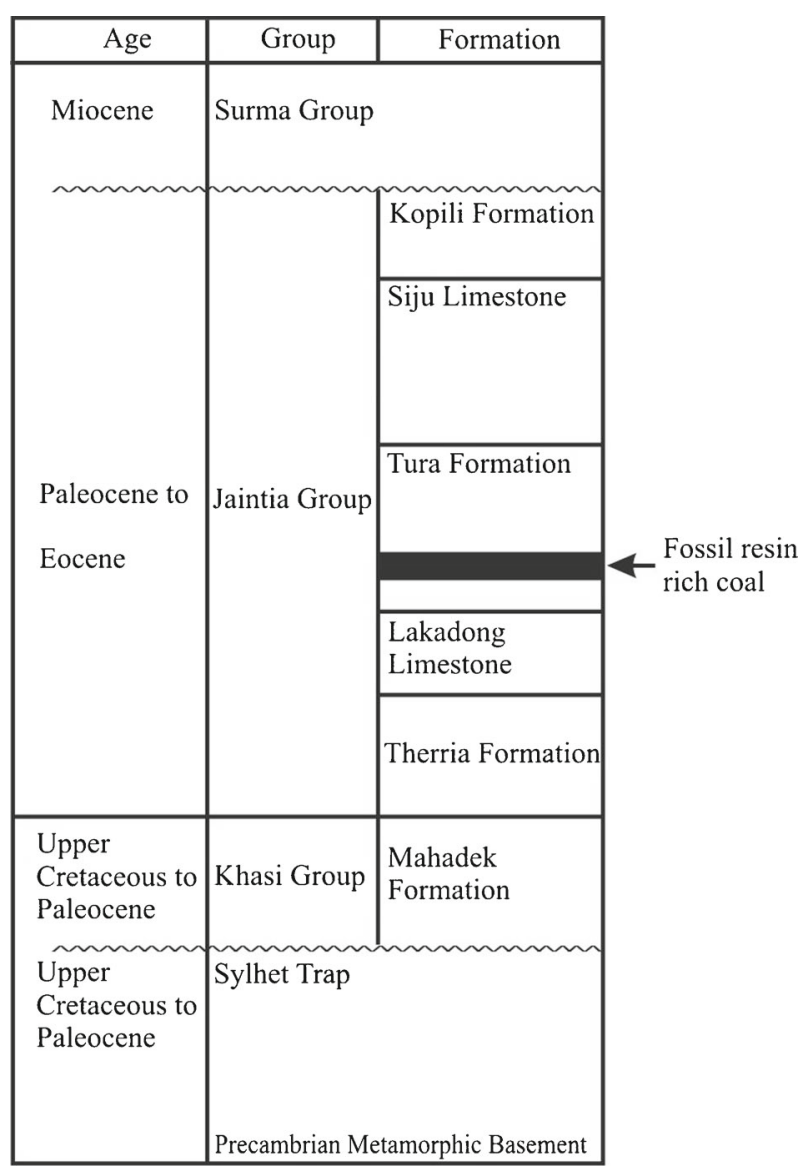

Figure 2. Localized stratigraphy of the area showing position of fossil resin rich coal.

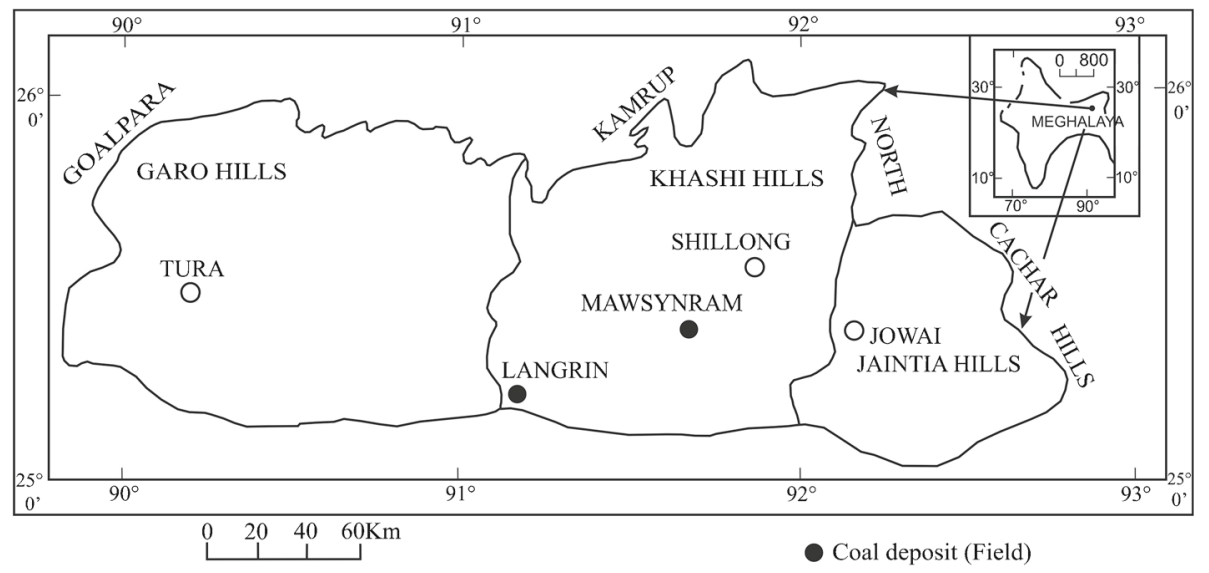

Figure 1. Location map of Langrin coal mine (modified after Behera 2007). 
ion source was operated in the electron ionization mode at $70 \mathrm{eV}$. During analysis, the temperature of $\mathrm{GC}$ oven was initially held at $40^{\circ} \mathrm{C}$ for $5 \mathrm{~min}$ and then increased to $310^{\circ} \mathrm{C}$ at $4^{\circ} \mathrm{C} / \mathrm{min}$ and finally held for 5.5 minutes. The samples were dissolved in dichloromethane and injected by autosampler in pulsed splitless mode. Peaks were identified based on GC retention time and mass spectra which were compared with published literatures and MS libraries. Chromatograms and mass spectra were processed using Chemstation software.

\subsection{Pyrolysis-gas chromatography-mass spectrometry}

The resin samples were pyrolyzed at $600^{\circ} \mathrm{C}$ for 5 minutes using a temperature programmed pyrolyzer (Double Shop Py-2020iD) coupled directly to a Thermo Finnigan gas chromatograph (GC) with a Trace BSQ mass spectrometer (MS). The GC was equipped with a $60 \mathrm{~m}$ fused silica capillary column with an inner diameter of $0.25 \mathrm{~mm}$. An initial oven temperature of $35^{\circ} \mathrm{C}$ was set and then ramped to $100^{\circ} \mathrm{C}$ at $25^{\circ} \mathrm{C} / \mathrm{min}$. Subsequently the temperature was ramped from $100^{\circ} \mathrm{C}$ to $310^{\circ} \mathrm{C}$ at $2^{\circ} \mathrm{C} / \mathrm{min}$. The MS was operated in electron impact mode at ionization energy of $70 \mathrm{eV}$ and a source temperature of $200^{\circ} \mathrm{C}$. Full scan mass spectra were recorded over a mass range of 50-500 Da. Peak assignments were based on correlation of GC retention time and mass spectral data to published literature and MS libraries. Chromatograms and mass spectra were processed with Xcalibur version 2.1.

\subsection{Fourier transform infrared spectroscopy}

FTIR spectroscopic analyses from 4000 to $400 \mathrm{~cm}^{-1}$ were performed in transmission mode with focal plane array $128 \times 128$ using Vertex 80 model operated by Opus software with a single point detector range $7500-450 \mathrm{~cm}^{-1}$ guided by $\mathrm{KBr}$ beam splitter. The analysis area was $128 \times 128$ in $2 \mathrm{D}$ format on the sample plane $300 \times 300 \mathrm{~m}$. The sample stage was temperature controlled and spectra were obtained for an area by co-adding up to 32 scans with a spectral resolution $4 \mathrm{~cm}^{-1}$. Peak assignments were based on published literature, e.g., Mallick et al. (2009) and Dutta et al. (2013).

\section{Results}

\subsection{Gas chromatography-mass spectrometry}

The total ion chromatogram (TIC) resulting from GC-MS of Langrin fossil resin is shown in figure 3.
The major compounds identified from the resin sample are $\mathrm{C}_{15}$ bicyclic sesquiterpenoids (table 1 ).

The resin sample from Langrin coal contains cadalene (4-isopropyl-1,6-dimethylnaphthalene MW 198), as the most abundant peak and methyl ionene (MW 188), as the second most abundant peak. The compounds with relatively higher abundance comprise pristane (MW 268) and $4 \beta(\mathrm{H})$ eudesmane (MW 208). Other compounds present in low abundance include ionene (MW 174), dihydroar-curcumene (MW 204), $\mathrm{C}_{16}$ homodrimaene (MW $222)$, calamenene (1,2,3,4-tetrahydrocadalene; $\mathrm{MW}$ 202) and 5,6,7,8-tetrahydrocadalene (8-isopropyl2,5-dimethyl-1,2,3,4-tetrahydronaphthalene; MW 202), as well as several naphthalene derivatives, such as trimethylnaphthalene (MW 170) and tetramethylnaphthalene (MW 184). Compounds with peaks at higher retention times (MW 394$408 \mathrm{Da})$ are attributed to angiosperm derived triterpenoid precursors. Most of them are derived from $\alpha$-amyrin and $\beta$-amyrin and are diagenetically altered.

\subsection{Pyrolysis-gas chromatography-mass spectrometry}

The selected ion chromatogram from the Py-GCMS of the resin is shown in figure 4. The major products identified from Py-GC-MS are bicyclic sesquiterpenoids such as cadalene (4-isopropyl-1,6dimethylnaphthalene; MW 198), calamenene (1,2, 3,4-tetrahydrocadalene; MW 202), methyl ionene (MW 188), dihydro-ar-curcumene (MW 204), ionene (MW 174) and 5,6,7,8-tetrahydrocadalene (8isopropyl-2,5-dimethyl-1,2,3,4-tetrahydronaphthalene; MW 202). Several alkylated benzenes and methylated naphthalenes such as trimethylnaphthalene (MW 170) and tetramethylnaphthalene (MW 184) were also relatively abundant in the pyrolysis products of the resin. In addition, a series of $n-\mathrm{C}_{17}-n-\mathrm{C}_{34}$ alkene-alkane pairs are identified which probably could be related to the coal within which the resin was embedded.

\subsection{Fourier transform infrared spectroscopy}

This technique gives information about the vibration and rotational modes of motion of the bonded atoms in a molecule and is used for the identification and characterization of functional groups. The FTIR spectrum of fossil resin is shown in figure 5 and the corresponding band assignments are enlisted in table 2 . The spectrum is characterized by intense bands between 3000 and $2800 \mathrm{~cm}^{-1}$ indicating dominant aliphatic $\mathrm{CH}_{x}$ stretching 


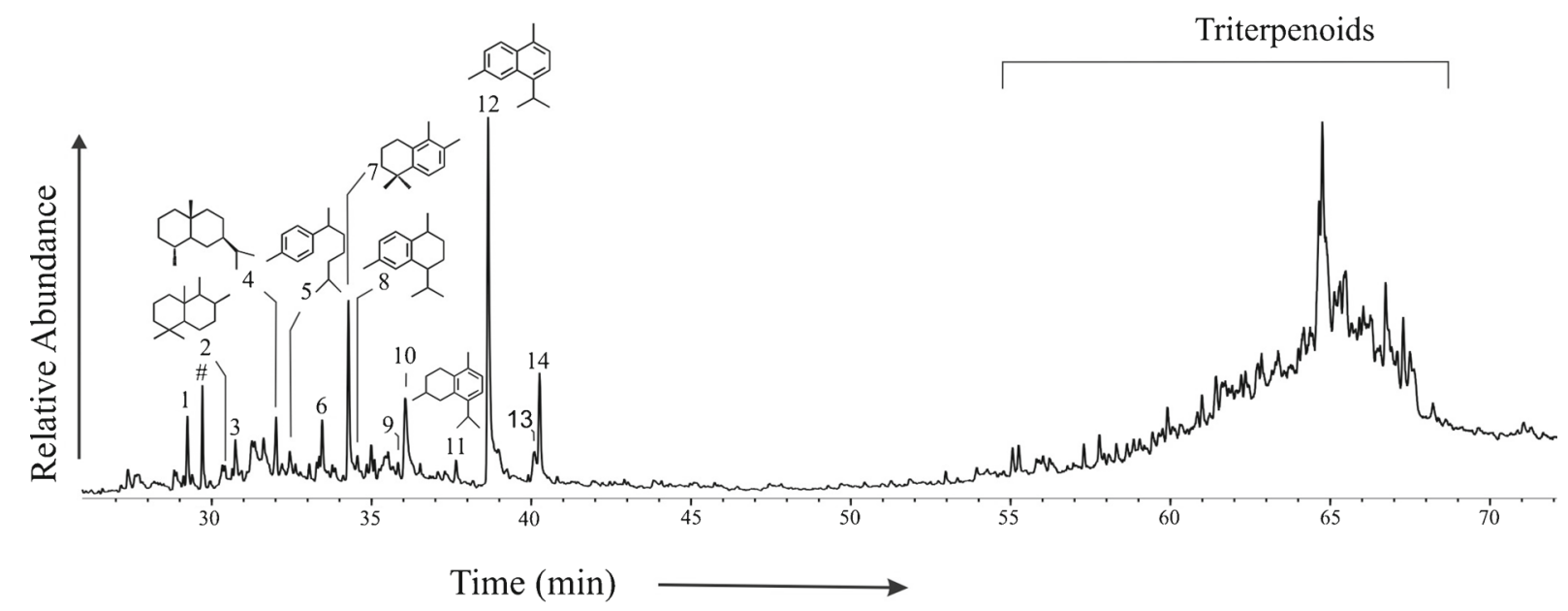

Figure 3. Total ion chromatograms resulting from GC-MS of Eocene resins from Langrin coal field, Meghalaya, northeast India. The identification of the numbered peaks is listed in table 1.

Table 1. Major compounds identified from the $G C-M S$ of Eocene resins from Langrin coal field, Meghalaya, northeast India.

\begin{tabular}{|c|c|c|}
\hline Peak & Compound name & $\begin{array}{c}\text { Molecular } \\
\text { weight }\end{array}$ \\
\hline 1 & Unknown $\mathrm{C}_{14}$ bicyclic sesquiterpenoid & 194 \\
\hline 2 & Unknown $\mathrm{C}_{15}$ bicyclic sesquiterpenoid & 208 \\
\hline 3 & Ionene & 174 \\
\hline 4 & $4 \beta(\mathrm{H})$ Eudesmane & 208 \\
\hline 5 & Dihydro-ar-curcumene & 204 \\
\hline 6 & Unknown compound & 188 \\
\hline 7 & Methyl ionene & 188 \\
\hline 8 & Calamenene & 202 \\
\hline 9 & Homodrimane & 222 \\
\hline 10 & Trimethyl naphthalene & 170 \\
\hline 11 & $5,6,7,8$-Tetrahydro cadalene & 202 \\
\hline 12 & Cadalene & 198 \\
\hline 13 & Tetramethyl naphthalene & 184 \\
\hline 14 & Pristane & 268 \\
\hline$\#$ & Contamination & 429 \\
\hline
\end{tabular}

vibrations where asymmetric and symmetric stretching vibrations are evident at 2950 and $2867 \mathrm{~cm}^{-1}$ respectively. The broad absorption peak at $3432 \mathrm{~cm}^{-1}$ is due to hydroxyl stretching. The absorption at $1456 \mathrm{~cm}^{-1}$ suggests symmetric bending of $\mathrm{CH}_{2}$ and asymmetric bending of $\mathrm{CH}_{3}$. Evidence of a symmetric deformational vibration of $\mathrm{CH}_{3}$ is recorded at $1376 \mathrm{~cm}^{-1}$. Less intense absorptions at 1705 and $1627 \mathrm{~cm}^{-1}$ can be attributed to carbonyl/carboxyl $\mathrm{C}=\mathrm{O}$ stretching and aromatic $\mathrm{C}=\mathrm{C}$ ring stretching vibrations respectively. From the FTIR data it can be inferred that the fossil resin was enriched with aliphatic compounds which are probably derived from the cyclic chains of $\mathrm{C}_{15}$ bicyclic sesquiterpenoids.

\section{Discussions}

Anderson et al. (1992) had classified resins into four classes based on their original structural character and composition. Class I resinites constitute polymers of labdatriene carboxylic acids, e.g., Baltic ambers. Class II resinites constitute polymers of sesquiterpenoids, e.g., dammar resins. Class III resins contain basic polystyrene structure, e.g., Storax and Class IV resins contain cedrane (also a sesquiterpenoid) based structure composed of non-polymeric units, e.g., Moravian resins. Cadinane based resins with basic sesquiterpeniod structure are derived from Dipterocarpaceae and subfamily Mastixioideae of the Cornaceae family of angiosperms (Anderson et al. 1992; van Aarssen et al. 1994). The Mastixiodeae subfamily is widespread in Cenozioc rocks of Europe and North America and is not reported from India and SE Asia till date (Dutta et al. 2011b). The presence of $\mathrm{C}_{15}$ bicyclic sesquiterpenoids along with cadalene in the studied resin suggests that these can be classified as Class II resins (Anderson et al. 1992) that are derived from Dipterocarpaceae family.

In India, the oldest report of Dipterocarpaceae is from early Eocene resins from Kutch and Cambay basins, western India (Dutta et al. 2009, 2011b, 2014; Mallick et al. 2009; Rust et al. 2010). The geochemical characterization of these resins has also been carried out from Miocene lignites in Kerala-Konkan, west coast of India (Dutta et al. 2010) and Cauvery Basin, east coast, India (Dutta et al. 2009). Khan and Bera (2010) have reported fossil winged fruits of Shorea Roxb. (a species from Dipterocarpaceae family) in Neogene sediments for the first time from eastern India. The origin of Dipterocarps has been debated as some authors postulated that they originated in SE 


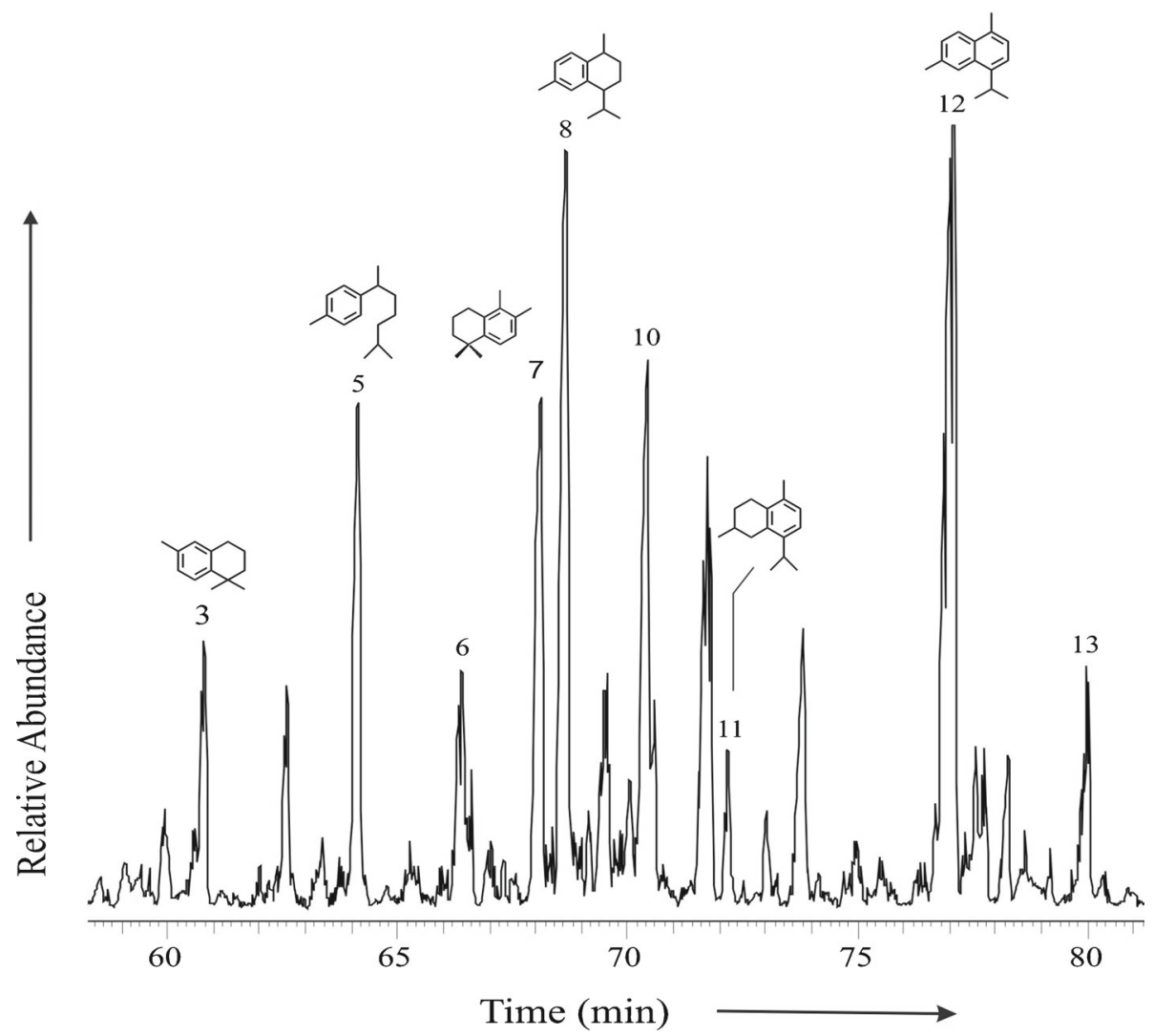

Figure 4. Selected ion chromatograms resulting from Py-GC-MS $(m / z 159+119+132+173+159+123+170+187+183+169)$ of Eocene resins from Langrin coal field, Meghalaya, northeast India. The identification of the numbered peaks is listed in table 1 .

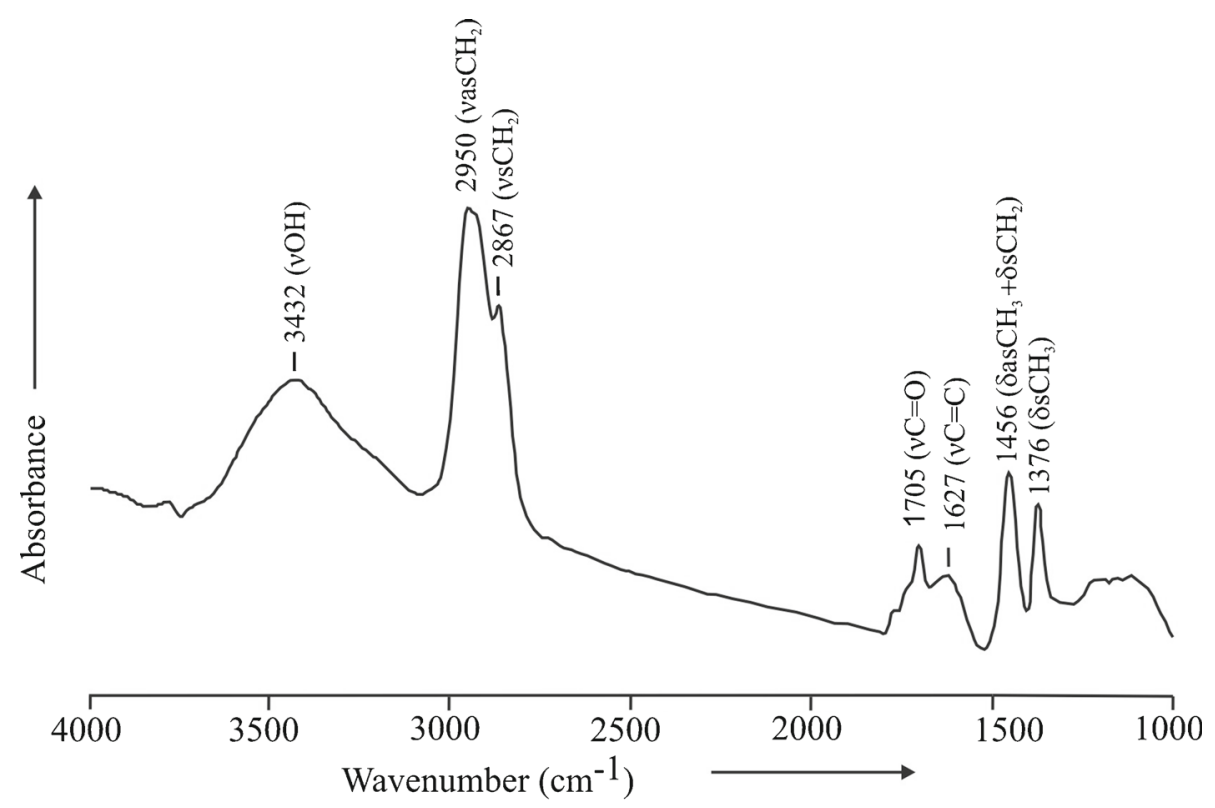

Figure 5. FTIR spectrum of fossil resin sample of Eocene resins from Langrin coal field, Meghalaya, northeast India. Assignments of absorption bands and vibration modes ( $\delta=$ deformation; $\nu=$ stretching; $\mathrm{s}=$ symmetric; as $=$ asymmetric $)$ are indicated in parentheses.

Asia and migrated into India when the land connection was established between India and Eurasia. This hypothesis is supported by the earliest record of Dipterocarpaceae resins from Oligocene (34-23 Ma) sediments of Borneo, SE Asia (Muller 1981). Other authors postulated that they have 
Table 2. Band assignments of FTIR spectra of fossil resins based on Dutta et al. (2013) and Mallick et al. (2009).

\begin{tabular}{ll}
\hline Bands $\left(\mathrm{cm}^{-1}\right)$ & \multicolumn{1}{c}{ Assignments } \\
\hline $3400-3320$ & -OH stretching \\
$3000-2800$ & Aliphatic $\mathrm{CH}$ stretching \\
$1710-1700$ & Carbonyl/carboxyl $\mathrm{C}=\mathrm{O}$ stretching \\
$1625-1560$ & Aromatic $\mathrm{C}=\mathrm{C}$ ring stretching \\
$1460-1445$ & Aliphatic $\mathrm{CH}_{2}$ and $\mathrm{CH}_{3}$ deformation \\
$1380-1350$ & Aliphatic $\mathrm{CH}_{3}$ deformation \\
$1280-1250$ & Aromatic ether $\mathrm{C}-\mathrm{O}-\mathrm{C}$, phenolic $\mathrm{C}-\mathrm{O}$ \\
& and ester $\mathrm{CO}-\mathrm{O}-\mathrm{C}$ stretching \\
$1060-1030$ & Aliphatic ether $\mathrm{C}-\mathrm{O}-\mathrm{C}$ and alcohol \\
& C-O stretching \\
\hline
\end{tabular}

originated in Gondwana, evolved in India since Paleogene (Prasad et al. 2009) and have dispersed into Asia (Dutta et al. 2011a) when there was land connection between Indian and Asian plates during early Eocene at ca. $50 \mathrm{Ma}$ (Scotese et al. 1988). Therefore it is possible that Dipterocarpaceae dominated and flourished in India during early Eocene. Dipterocarpaceae are generally characteristic of warm and humid climate, suggestive of tropical rainforests (Langenheim 1995). They constitute $30 \%$ of the total area of evergreen lowland forest and $80 \%$ of all emergent floras in SE Asian rainforest (Appanah 1993; Aiba and Kitayama 1999). Earlier reports of dammar resins of early Eocene age from western India, postulated a tropical climate (Dutta et al. 2011a). The early Eocene climate was globally intense with respect to temperature, humidity and rainfall (Zachos et al. 2008; Prasad et al. 2009; Clementz et al. 2011). It therefore suggests that a warm tropical climate existed during early Eocene and was supportive for the growth of Dipterocarpaceae.

\section{Conclusions}

The resin extracts are characterized by cadalenebased $\mathrm{C}_{15}$ sesquiterpenoids and diagenetically altered triterpanes. Pyrolysis products are also characterized by cadalene-based $\mathrm{C}_{15}$ sesquiterpenoids along with alkylated benzenes and methylated naphthalenes. The presence of these compounds indicates that the resin can be classified as Class II or dammar resin which is probably derived from Dipterocarpaceae, a family of angiosperms characteristic of warm, humid and tropical climate. This is probably the earliest record of tropical rainforest element from northeastern India and suggests that this type of vegetation was not only restricted to western India but also existed in eastern India.

\section{Acknowledgements}

Oil India Limited (OIL), Duliajan is acknowledged for providing financial support for the present research work. University Grants Commission (UGC) is also acknowledged for providing financial support to Arka Rudra. The authors thank Mr R K Bordoloi, OIL, Duliajan for analyzing the samples using Py-GC-MS. The authors are grateful to SAIF, IIT Bombay for giving access to FTIR instrument. IIT Bombay is acknowledged for providing support and infrastructure for research work. They are highly grateful to Prof. Ksenija Stojanović and an anonymous reviewer for their valuable inputs and comments. They also thank Prof. Anindya Sarkar, Associated Editor of the journal for handling the review process.

\section{References}

Aiba S I and Kitayama K 1999 Structure, composition and species diversity in an altitude substrate matrix of rain forest tree communities on Mount Kinabalu, Borneo; Plant Ecol. 140 139-157.

Anderson K B and Muntean J V 2000 The nature and fate of natural resins in the geosphere. Part X. Structural characteristics of the macromolecular constituents of modern dammar resin and Class II ambers; Geochem. Trans., doi: 10.1039/b000495m.

Anderson K B, Winans R E and Botto R E 1992 The nature and fate of natural resins in the geosphere-II. Identification, classification and nomenclature of resinites; Org. Geochem. 18 829-841.

Appanah S 1993 Mass flowering of dipterocarp forests in the aseasonal tropics; J. Biosci. 18 457-474.

Behera P 2007 Volatile displacement of Meghalaya coals - A pointer to explore low sulphur coals; J. Earth Syst. Sci. 116 137-142.

Bray P S and Anderson K B 2009 Identification of carboniferous (320 Million years old) Class Ic amber; Science $\mathbf{3 2 6}$ $132-134$.

Clementz M, Bajpai S, Ravikant V, Thewissen J G M, Saravanan N, Singh I B and Prasad V 2011 Early Eocene warming events and the timing of terrestrial faunal exchange between India and Asia; Geol. 39 14-18.

Dutta S, Mallick M, Bertram N, Greenwood P F and Mathews R P 2009 Terpenoid composition and class of Tertiary resins from India; Int. J. Coal Geol. 80 44-50.

Dutta S, Mallick M, Mathews R P, Mann U, Greenwood P F and Saxena R 2010 Chemical composition and palaeobotanical origin of Miocene resins from Kerala-Konkan coast, western India; J. Earth Syst. Sci. 119 711-716.

Dutta S, Mallick M, Kumar K, Mann U and Greenwood P F 2011a Terpenoid composition and botanical affinity of Cretaceous resins from India and Myanmar; Int. J. Coal Geol. 85 49-55.

Dutta S, Tripathi S M, Mallick M, Mathews R P, Greenwood P F, Rao M R and Summons R 2011b Eocene out-of-India dispersal of Asian dipterocarps; Rev. Palaeobot. Palynol. 166 63-68.

Dutta S, Hartkopf-Fröder C, Witte K, Brocke R and Mann U 2013 Molecular characterization of fossil palynomorphs by transmission micro-FTIR spectroscopy: Implications 
for hydrocarbon source evaluation; Int. J. Coal Geol. 115 $13-23$.

Dutta S, Saxena R and Singh H 2014 Exceptional preservation of angiosperm markers in Miocene and Eocene ambers; Geol. doi: 10.1130/G34975.1.

Huang B, Xiao X and Zhang M 2003 Geochemistry, grouping and origins of crude oils in the Western Pearl River Mouth Basin, offshore South China Sea; Org. Geochem. 34 993-1008.

Khan M A and Bera S 2010 Record of fossil fruit wing of Shorea Roxb. from Neogene of Arunachal Pradesh; Curr. Sci. 98 1573-1574.

Langenheim J H 1995 Biology of amber-producing trees: Focus on case studies of Hymenaea and Agathis; In: Amber, Resinite, and Fossil resins (eds) Anderson K B and Crelling J C, ACS Symp. Series 617 1-31.

Mallick M, Dutta S, Greenwood P F and Bertram N 2009 Pyrolytic and spectroscopic studies of Tertiary resin from Vastan Lignite Mine, Cambay Basin, western India; Geol. Soc. India 74 16-22.

Mukherjee K N, Dutta N R, Chandra D and Singh M P 1992 Geochemistry of trace elements of Tertiary coals of India; Int. J. Coal Geol. 20 99-133.

Muller J 1981 Fossil pollen records of extant angiosperms; Botanical Review 47 1-142.

Murray A P, Edwards D, Hope J M, Boreham C J, Booth W E, Alexander R A and Summons R E 1998 Carbon isotope biogeochemistry of plant resins and derived hydrocarbons; Org. Geochem. 29 1199-1214.

Prasad V, Farooqui A, Tripathi S K M, Garg R and Thakur B 2009 Evidence of Late Palaeocene-Early Eocene equatorial rain forest refugia in southern Western Ghats, India; J. Biosci. 34 777-797.

Rust J, Singh H, Rana R S, McCann T, Singh L, Anderson K, Sarkar N, Nascimbene P C, Stebner F, Thomas J C, Solórzano-Kraemera M, Williams C J, Engel M S, Sahni A and Grimaldi D 2010 Biogeographic and evolutionary implications of a diverse paleobiota in amber from the early Eocene of India; Proc. Nat. Acad. Sci. USA 107 $18,360-18,365$.

Scotese C R, Gahagan L M and Larson R L 1988 Plate tectonic reconstructions of the Cretaceous and Cenozioc ocean basins; Tectonophys. 155 27-48.

Singh M P and Singh A K 2000 Petrographic characteristics and depositional conditions of Eocene coals of platform basins, Meghalaya, India; Int. J. Coal Geol. 42 315-356.

van Aarssen B G K and de Leeuw J W 1992 High-molecular mass substances in resinites as possible precursors of specific hydrocarbons in fossil fuels; Org. Geochem. 19 $315-326$.

van Aarssen B G K, de Leeuw J W, Collinson M, Boon J $\mathrm{J}$ and Goth K 1994 Occurrence of polycadinene in fossil and recent resin; Geochim. Cosmochim. Acta 58 223-229.

van Bergen P F, Collinson M E, Scott A C and de Leeuw J W 1995 Unusual resin chemistry from Upper Carboniferous pteridosperm resin rodlets; In: Amber, Resinite, and Fossil resins (eds) Anderson K B and Crelling J C, ACS Symposium Series; Am. Chem. Soc. 617 105-129.

Zachos J C, Dickens G R and Zeebe R E 2008 An early Cenozoic perspective on greenhouse warming and carboncycle dynamics; Nature 451 279-283. 